\title{
Differentiation pathways in carcinogenesis and in chemo- and radioresistance
}

\author{
Minireview
}

M. JANIKOVA, J. SKARDA*

Laboratory of Molecular Pathology, Department of Clinical and Molecular Pathology and Institute of Molecular and Translational Medicine: Faculty of Medicine and Dentistry, Palacky University and University Hospital Olomouc, Czech Republic

*Correspondence: jojos@email.cz

Received March 18, 2011 / Accepted September 7, 2011

\begin{abstract}
Cancer stem cells (CSCs) share many features with embryonic stem cells (ESCs) such as the ability for self-renewal and differentiation. Signaling pathways that are involved in these processes are also involved in chemo- and radioresistance (e.g. Wnt, Notch and Hedgehog pathways). This review is focused on the influence of three important differentiation pathways on carcinogenesis and on chemo- and radioresistance in ESCs and CSCs.
\end{abstract}

Key words: Stem cell, Chemoresistance, Radioresistance, Wnt pathway, Notch pathway, Hedgehog pathway

Differentiation signaling pathways (e.g. Wnt, Notch and Hedgehog) are active in stem cells. Nowadays, embryonic stem cells (ESCs) and cancer stem cells (CSCs) are the most studied types of stem cells. They share many common characteristics, e.g. self-renewal, unlimited proliferative potential, ability to differentiate in certain cell types and cell detoxification by special molecules; but there are also some differences between both cell types (Tab. 1). Stem cell hallmarks are termed as markers of "stemness" [1-5].

ESCs have been first time isolated from inner cell masses of late mouse blastocyst cells [6]. Human ESCs have been isolated in 1998. These cell lines have normal karyotypes [unlike embryonic cancer cells (ECCs)], high telomerase activity and surface markers specific for primate ESCs [7].

Tumor cells possessing self-renewal ability, multilineage differentiation and maintenance of malign growth are termed cancer stem cells (CSCs). Tumor cells are surrounded with microenvironment called tumor niche. Factors maintaining the CSCs in self-renewing and undifferentiated state are presented in this niche [8]. ESCs have not stable niche in vivo, because during embryo development they are attendant only transiently [9]. Factors in the ESC niche are changed depending on the ESC final destination.
Cancer stem cells (CSCs) have been isolated from tumors of diverse organs, for example blood, breast, brain, lung, prostate, colon, liver, pancreas and skin. [10]. Fluorescence-activated cell sorting (FACS) by flow cytometer is used for isolation of side population (SP) enriched by CSCs on the basis of the ability to exclude Hoechst 33342 stain by ABCG2, or other members of the $\mathrm{ABC}$ (ATP-binding cassette)-transporter family, such as ABCB1 (P-glycoprotein or MDR-1), ABCC1 (MRP-1) and ABCA2 [11, 12]. Recently, drug surviving cells (DSCs) were isolated from human cancer cell lines exposed to cisplatine, doxorubicin and ectoposid. These cells share the same main characteristics as CSCs (self-renewal, clonogenic potential, expression of specific markers and the ability to differentiate). From this point of view DSCs can be considered CSCs [13].

Major mechanisms of radio- and chemoresistance in ESC and CSC. Most of the cancer cells are destroyed during the treatment, but some of these (CSCs) survive. Stem cells express many pumps (such as ABC-transporters ABCB1, ABCC1, ABCG2) which are able to exclude chemotherapeutic agents out of the cells and enzymes metabolising drugs [e.g. ALDH1 (aldehyde dehydrogenase 1), GST4 (glutathione S-transferase 4)]. They also produce DNA repair [e.g. Ku80, MGMT (O-6-methylguanine-DNA methyltransferase), BRCA1 (breast 
Table 1. ESC and CSC features

\begin{tabular}{|c|c|c|c|}
\hline Feature & ESC & CSC & References \\
\hline Self-renewal potential & Yes & Yes & $1-4$ \\
\hline Differentiation potential & Pluripotent & Multipotent & $1-4$ \\
\hline Toxic stress response & Yes & Yes & $2-4,14,15$ \\
\hline DNA-repair mechanisms & Active & Active & 14,16 \\
\hline Anti-apoptotic mechanisms & Active & Active & 14,16 \\
\hline Stem cell niche & Changing & Stabile & 8,9 \\
\hline The role of Wnt signaling & $\begin{array}{l}\text { Cell-fate determination, anterior-posterior body } \\
\text { orientation, formation of primitive streak, meso- } \\
\text { derm and endoderm, apoptosis prevention }\end{array}$ & $\begin{array}{l}\text { Cell migration during metastasis formation, ap- } \\
\text { optosis, chemo- and radioresistance, maintenance } \\
\text { of CSCs }\end{array}$ & $\begin{array}{l}16,27,40,41,44-47 \\
49,53,54,56-58\end{array}$ \\
\hline The role of Notch signaling & $\begin{array}{l}\text { Boundary formation, lateral inhibition, cell- } \\
\text { fate assignation, several organs and systems } \\
\text { development }\end{array}$ & $\begin{array}{l}\text { Epithelial-mesenchymal transition during progres- } \\
\text { sion and metastasing of tumors, pro-/anti-apoptotic } \\
\text { effect, chemo- and radioresistance, self-renewal or } \\
\text { cell fate decision or terminal differentiation }\end{array}$ & $\begin{array}{l}15,68,69,72,77-79 \\
82,88-92,102,103\end{array}$ \\
\hline The role of Hedgehog signaling & Organs development, proliferation & $\begin{array}{l}\text { Growth, self-renewal and metastatic potential, } \\
\text { apoptosis prevention }\end{array}$ & $\begin{array}{l}15,110,112-116, \\
125,126,\end{array}$ \\
\hline
\end{tabular}

cancer type 1 susceptibility protein)] and other anti-apoptotic proteins [(e.g. BCL-2, BCL-XL, FLIP (flice inhibitory protein)] preventing the cells against apoptosis. The big problem for targeting stem cells by chemotherapeutic agents is a slow rate of cell turnover because these drugs naturally impair cell cycle in rapidly replicating cells [14-16].

Another mechanism how stem cells protect themselves against anti-cancer therapy is that these cells produce growth and angiogenic factors encouraging tumor recurrence. Angiogenesis and metastasis formation are at least in part managed by the niche, that might protect CSCs from radio- and chemotherapies $[8,17,18]$. The radiation therapy modifies the tumor niche. It leads to the enhanced expression or activation of many anti-apoptotic proteins or pro-inflamatory cytokines, or tumor promoting factors [19]. VEGF (vascular endothelial growth factor) receptors activation stimulates CSCs proliferation and protects them from drug-induced apoptosis [13].

Similarly, HIF1 (hypoxia inducible factor 1) is responsible for tumor radiotherapy-response. Depending on other factors in the niche, HIF1 either induces ATP (adenosine-5'-triphosphate) metabolism, proliferation or apoptosis by p53 activation (cell sensitization to the therapy), or it allows CSCs to survive (tumor growth maintenance) [20]. Therefore, the use of drugs that inhibit HIF1 may have a double effect.

Under hypoxic conditions the expression of transcription factor (TF) OCT4 is activated due to the HIF [21]. Recently, it was observed in lung cancer that increased level of OCT4 may provide tumor resistance to the chemo-radiation therapy. It seems that OCT4 is linked with P-glycoprotein, member of the $\mathrm{ABC}$-transporter family, and thus it may participate in the emergence of multidrug resistance (MDR) [22].

Other downstream targets of TFs OCT4 and SOX2 are responsible for the drug resistance of ESCs. TF ZFP206 (zinc finger protein 206) provides them the resistance to the retinoic acid-induced differentiation [23], TF ZIC3 (zinc finger protein of the cerebellum 3) prevents endodermal specification in ESCs [24] and ESG1 regulates the pluripotency and the development of primordial germ cells (PGCs) [25].

Differentiation pathways involved in carcinogenesis and in radio- and chemoresistance. For maintaining stem cells characteristics, the specific pathways supporting these processes must be active. These pathways are responsible for the cell-fate determination of ESCs, since they downregulate the expression of certain target genes affecting cell differentiation. Among these constitutive mechanisms with this ability are Wnt, Hedgehog and Notch signaling pathways $[26,27]$.

Wnt signaling pathway. The Wnt signaling pathway is activated by secreted WNT glycoproteins (a gene family consisting of 19 members) binding to the 7-transmembrane (TM) receptor of the Frizzled (FZD) family. Human ESCs express all WNTs and most FZDs, while in multipotent cells, for example human mesenchymal cells (MSCs) and in the ECCs, the expression of certain WNTs and FZDs is missing $[28,29]$. Depending on associated co-receptor, signals are transmitted in two different ways. When FZD cooperates with LRP5/6 (low-density lipoprotein receptor-related proteins 5 and 6) [30], the so-called canonical pathway participation in $\beta$-catenin stabilisation is activated (Fig. 1a) [31]. For this reason it is also called a Wnt/ $\beta$-catenin signaling pathway [32]. Target genes of this pathway participate in self-renewal, pluripotency, proliferation and cell-fate determination $[(c-M y c$, Cyclin D1, MMPs (matrix metalloproteinase), VEGF, NOS2 (nitric oxide synthase 2), PPAR $\delta$ (peroxisome proliferatoractivated receptor- $\delta$ ), COX-2 (cyclooxygenase-2), JAG1, CER1 (cerberus 1)] [33-36]. When FZD collaborates with ROR2/RYK co-receptors, the non-canonical pathway is triggered. This in turn depends on $\mathrm{Ca}^{2+}$ and G-proteins that activate kinase cascades (Fig. 1b) [37].

During carcinogenesis, activation of Wnt $/ \beta$-catenin signaling is often involved through upregulation of Wnt ligands or 
(a)

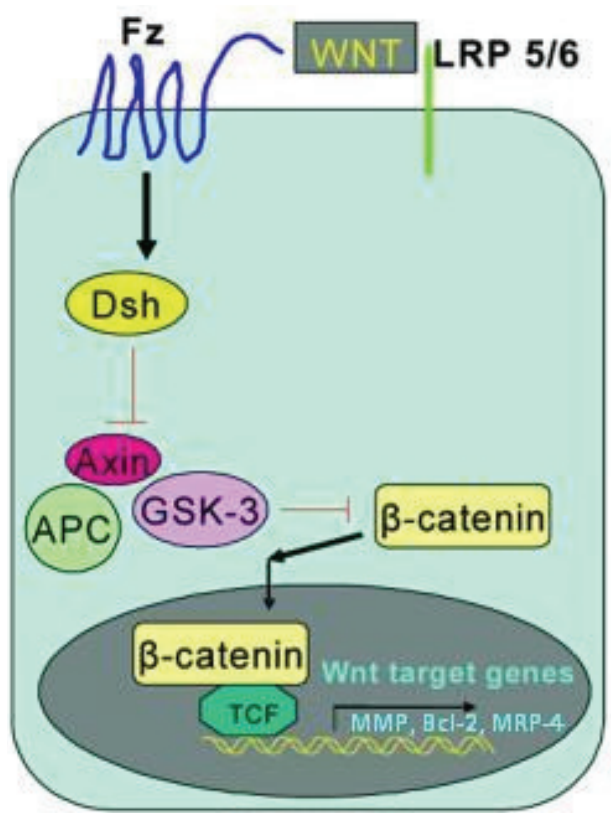

(b)

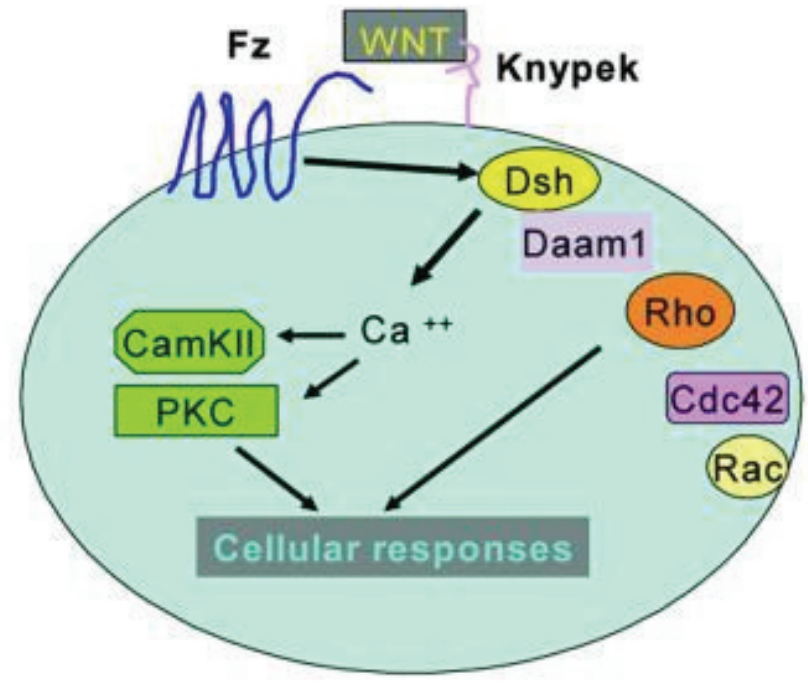

Figure 1. Wnt signaling

a) Canonical pathway activated in the presence of certain Wnt ligands through Dishevelled (DVL) phosphorylation leads to the inactivation of $\beta$-catenin destruction complex consisting of APC (adenomatous polyposis coli), scaffold protein AXIN and GSK3 $\beta$ (glycogen synthase kinase $3 \beta$ ). $\beta$-catenin is translocated to the nucleus where it is complexed with TCF/LEF (T-cell factor/lymphoid enhancer factor) family transcription factor. In the absence of the activating Wnt signals, GSK3 $\beta$ phosphorylates $\beta$-catenin. Thus, GSK3 $\beta$ predestinates $\beta$-catenin for the ubiquitination and subsequent degradation in proteasomes.

b) Wnt signals of non-canonical pathway either phosphorylate DVL activating small G-proteins (RHO, RAC, CDC42) and JNK, that through MAP-kinase cascade transmit the signal up to the nucleus, or they release $\mathrm{Ca}^{2+}$ affecting NLK (Nemo-like kinase) or NFAT (nuclear factor of activated T-cells). This inhibits the canonical Wnt signaling pathway and facilitates cytoskeletal reorganization during invasion and metastasis. [31].

FZD receptors. Parallelly, $\beta$-catenin degradation is stopped due to failure of some upstream members of the signaling pathway, and/or the $\beta$-catenin is mutated $[38,39]$. Intracellular accumulation of $\beta$-catenin and its translocation into the nucleus regulates the expression of target genes, or it forms complexes with E-cadherin in the cytoplasmatic membrane, thereby it becomes a part of cell-cell contacts. In this manner, $\beta$-catenin may be involved in cell migration during metastasis [40]. Negative regulators, such as sFRP (secreted Frizzled-related protein), AXIN and PPAR $\gamma$ (peroxisome proliferator-activated receptor $\gamma$ ), can be silenced or mutated [37, 41, 42]. As Wnt signaling is connected to the chromosome orientation during mitosis, its perturbations may lead to a mitotic disjunction typical of many cancer cells [43].

Wnt signaling is active in both CSCs and ESCs. In ESCs it has been shown, that Wnt signaling manages the undifferentiated cell proliferation depending on the type of Wnt ligand and others factors. The Wnt pathway itself fails to maintain these cells in the pluripotent state. Its activity increases at the stage when the cell makes the decision which direction of differentiation will develop. In quiescent ESCs, the OCT4/SOX2 pathway is first activated and during cell-fate determination Wnt signaling is enhanced $[44,45,27]$. At that time, the Wnt pathway regulates the anterior-posterior body orientation [46] and formation of primitive streak, mesoderm and endoderm [47]. Wnt signaling is also necessary for the maintenance of the progenitor cells pool [26].

Wnt signaling is not a single unit but depending on the cell type it collaborates with other cell factors. It cooperates with several signaling pathways (e.g. Hedgehog, Notch, TGF $\beta$, PI3K/AKT, Src/ERK, Activin/Nodal, FGF) [31, 48-50], and also with many nuclear receptors (NRs), such as the androgen receptor (AR), the retinoic acid receptor (RAR), the vitamin $\mathrm{D}$ receptor (VDR), the progesterone receptor $(\mathrm{PR})$ and PPAR. $\beta$-catenin acts in their transcription as a co-activator. NRs serve as transcription factors, but they also affect posttranslational events, such as phosphorylation. Thus they can interact with other signaling pathways, including the Wnt [51]. Further, NRs (AR, RAR amd VDR) act as repressors of Wnt/ $\beta$-catenin signaling [52], since they can increase $\beta$-catenin accumulation in the plasma membrane in conjunction with E-cadherin. In this way its nuclear levels decline and stabilisation of the adherent junction is increased [51].

During both embryogenesis and carcinogenesis, Wnt ligands prevent apoptosis in progenitor cells. When DNA is damaged, the $\beta$-catenin affinity to TCF (T-cell factor) is in- 
creased due to PARP- 1 , and for this reason, $\beta$-catenin target genes expression is found [53]. Some of these genes may be responsible for the emergence of resistance to therapy, for example MMPs, Livin, BCL-2 and MRP4. MMPs through EGFR (epidermal growth factor receptor) activate the Src/ERK signaling pathway which may contribute to the emergence of endocrine therapy resistance [41]. Livin, a member of the IAP (inhibitor of apoptosis) family, prevents cell apoptosis and thus takes part in the development of tumor cell chemoresistance [54]. PI3K/AKT signaling is activated by the non-canonical Wnt pathway. Both Wnt pathways (canonical and non-canonical) regulate the expression of anti-apoptotic protein BCL-2 [49]. This is one of the anti-apoptotic mechanisms in stem cells. For this reason, the $\mathrm{Wnt} / \beta$-catenin signaling pathway activation may be involved in tumorigenesis by promoting cell survival [55]. Radiotherapy leads to breaks in the DNA molecule, but since apoptosis is blocked, the cell switches on reparation mechanisms and survives. In this way, Wnt signaling is also involved in CSC radioresistance [56]. ABCC4, known as MRP4 (multidrug resistance protein 4), is also the target gene of Wnt signaling. It is an ABC-transporter and participates in the transport of cyclic nucleotides and some nucleoside monophosphate analogs [57]. Therefore, treatment with these chemotherapeutic agents fails in the presence of MRP4 and the cells become chemoresistant.

Recently, it has been found that Wnt/ $\beta$-catenin signaling is one of the key pathways in the maintenance of CSCs (for example in lung, colon, liver, leukemia, melanoma, breast and skin cancer) [58]. Surprisingly, this pivotal role of Wnt/ $\beta$-catenin signaling is not so evident in human ESCs because inhibition of this pathway alone does not influence their self-renewal potential. It depends on collaboration with other signaling pathways and especially, on the origin of ESCs (e.g. mouse, rat or human ESCs) [44].

"The stemness" of colon CSCs depends not only on the presence of mutations in APC or $\beta$-catenin but also on myofibroblast-secreted factors which are able to restore the CSC phenotype in more differentiated tumor cells [59]. Other examples of molecules presented in the microenvironment during carcinogenesis and cancer are the inflammatory tissue products, interleukins (ILs). These stimulate the signaling pathways that regulate expression of Wnt ligands. IL6 induces through JAK/STAT3 signaling in CSCs, the activity of both canonical and non-canonical Wnt pathways and therefore it takes part in self-renewal and also metastasis. Under physiological conditions this activation maintains tissue homeostasis [60]. In the presence of different inflammatory cytokines, NOS2 expression is increased through TBE (Tcf-binding element) [34].

A number of substances have been found recently to inhibit the Wnt signaling pathway. Some of these, such as non-steroidal anti-inflammatory drugs (NSAIDs) (for example aspirin and indomethacin) and vitamins (retinoids and vitamin D), are used in the treatment of inflammatory diseases [61-63]. Others are developed for the treatment of cancer, such as the tyrosinekinase inhibitors (e.g. imatinib) [64] and some substances are chemical compounds, like lithium, curcumin and flavonoids [65]. Many small molecules [for example 6-bromoindirubin3 '-oxime (BIO), deoxycholic acid and pyrimidine derivates] inhibit Wnt signaling, but there are also agents that support Wnt activation (e.g. GS11 - increases the level of free $\beta$-catenin by dissociation of binding with E-cadherin) [66]. In mouse ESCs, the small molecule IQ-1 can support long-term pluripotency. The destiny of ESC has been reported to depend on $\beta$-catenin co-activators. If CBP (CREB binding protein) is present, the expression of transcription factors maintaining pluripotency (OCT4, SOX2) occurs. After CBP switching by p300, the cell initiates differentiation (e.g. c-MYC expression). IQ- 1 blocks the switching by p300 co-activator and guarantees mouse ESCs their pluripotency [67].

Apparently, Wnt signaling takes place in different processes during embryogenesis and carcinogenesis, but it cooperates with many other signaling pathways in a species-specific manner. These facts markedly complicate any definition of the exact function of the Wnt pathway.

Notch signaling pathway. Notch signaling differs from other signaling pathways mainly in activation by cell-cell contact. The Notch receptor is a single transmembrane protein composed of intra- and extracellular regions with distinct domains responsible for its specific functions. Notch ligands are also single transmembrane proteins. In mammals, four types of Notch receptors (Notch1 -4) and five types of Notch ligands [Delta-like1, 3, 4 (DLL1, 3, 4) and Jagged1 and 2 (JAG1, 2)] have been described [68]. When the ligand binds to the receptor, the transfer of signal is activated (Fig. 2) [69]. However, the high levels of ligand may have, conversely, an inhibitory effect [70, 71]. Target genes (transcription factors HES (hairy/ enhancer of split) and HERP (HES-related repressor protein family) are bHLH (basic helix-loop-helix) transcriptional repressors maintaining the self-renewal potential in the stem cells. During development they govern boundary formation, lateral inhibition and cell-fate assignation (differentiation, proliferation or apoptosis). Likewise, they contribute to the emergence of developmental diseases and tumors, as well as to EMT (epithelial-mesenchymal transition) during tumor metastasis $[68,69,72]$.

Boundary formation is a necessary event in development. For example, in vertebrates it is involved in somite formation. The oscillation of Notch signaling is controlled by WNT3a, which is evidence of Notch with Wnt signaling cooperation $[73,74]$. Lateral inhibition is a process by which the cells over the Notch signaling inhibit differentiation potential in neighbouring cells [e.g. the selection for sensory organ precursor (SOP) in Drosophila neurogenesis, or in mice development of hair cell in the inner ear] $[75,76]$. The cell-fate assignation is a determination of the fate of two daughter cells. These acquire a variable differentiation potential and therefore are able to differentiate into distinct cell types. For instance, different regulators (Numb and Neuralized) are involved in asymmetric cell division during SOP. These regulators are asymmetrically distributed among the daughter cells. After 


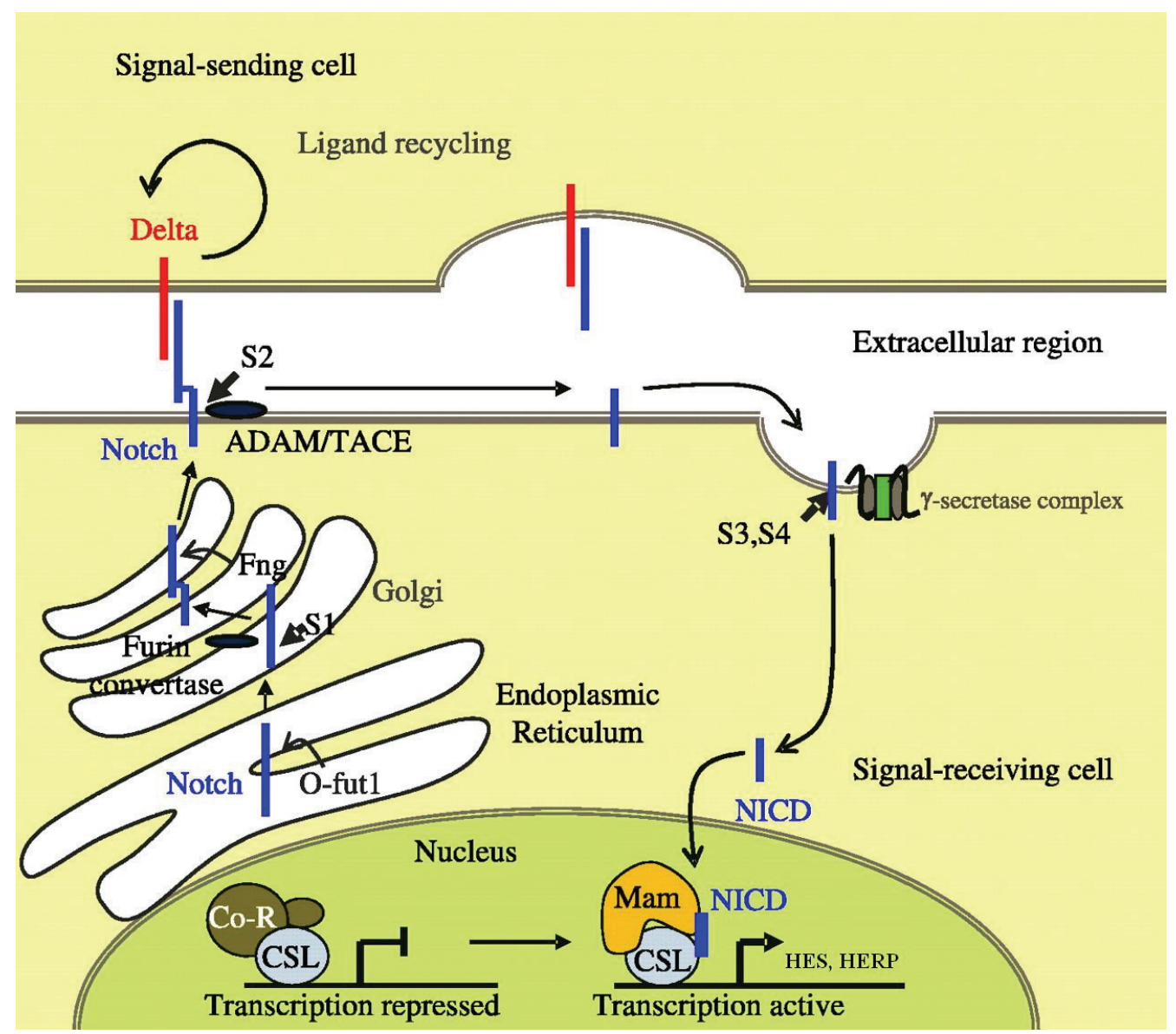

Figure 2. Notch signaling

The first step after the Notch receptor interaction with Notch ligand is the Notch receptor splicing in the site S2 by ADAM/TACE (a desintegrin and metallopeptidase/tumor necrosis factor a converting enzyme) family. It is followed by the cleavage at transmembrane site S3/S4 by $\gamma$-secretase. NICD (Notch intracellular domain) is chipped and transported by endocytosis to the nucleus. There it displaces a repressor (co-R) linked with histone deacetylase (HDAC) and associates with transcription factor CSL (C-promoter binding factor 1, RBP-jk/Su(H)/Lag-1) and co-activator mastermind (MAM). They together generate a ternary complex and support the activation of target genes [69].

four cycles of division, five cell types arise (socket, shaft, sheath, neuron and glial cells) [69]. In this way the stem cell population can be maintained [77]. Notch signaling may also be involved in the development of several organs and systems, such as the pituitary gland, gut, nervous and vascular system [77-79].

During very early embryogenesis, Notch signaling activity is not required. Even in human ESCs Notch signaling is inactive. In pluripotent ESCs, the transcription factors NANOG, OCT4 and SOX2 are necessary for self-renewal whereas $\mathrm{NOTCH} 1$ expression is very low. However, the level of these transcription factors decreases after cell-fate determination (in multipotent stem cells and in ECCs) and the NOTCH1 expression increases [80, 81, 29]. Notch signaling activation does not disturb the ESC differentiation and in some cases it is necessary (e.g. T-cell differentiation) [82]. The cells with active Notch pathway cannot differentiate into nervous system cells, but they maintain a neural stem/progenitor cell pool. They can also differentiate into other developing lines. The lineage commitment depends on the ligand. Recently, it was reported that Notch signaling activated by JAG1 promotes neural commitment in contrast to activation by DLL4 which promotes mesodermal commitment [83-85]. Notch signaling has to be completely switched off before terminal differentiation [86]. The differentiation and maintenance of the stem/progenitor cell pool by Notch signaling in mammary gland or hair formation is regulated by the same inhibition mechanism $[87,76]$. The regulation of apoptosis by the Notch pathway is quite controversial. It has pro-apoptotic, as well as anti-apoptotic effects. For example, in endothelial cells or keratinocytes apoptosis is promoted by inactivation of Wnt, respectively PI3K pathways. However, in tumors, where the PI3K pathway is activated, the cells are protected against the upcoming apoptosis [88-92]. 


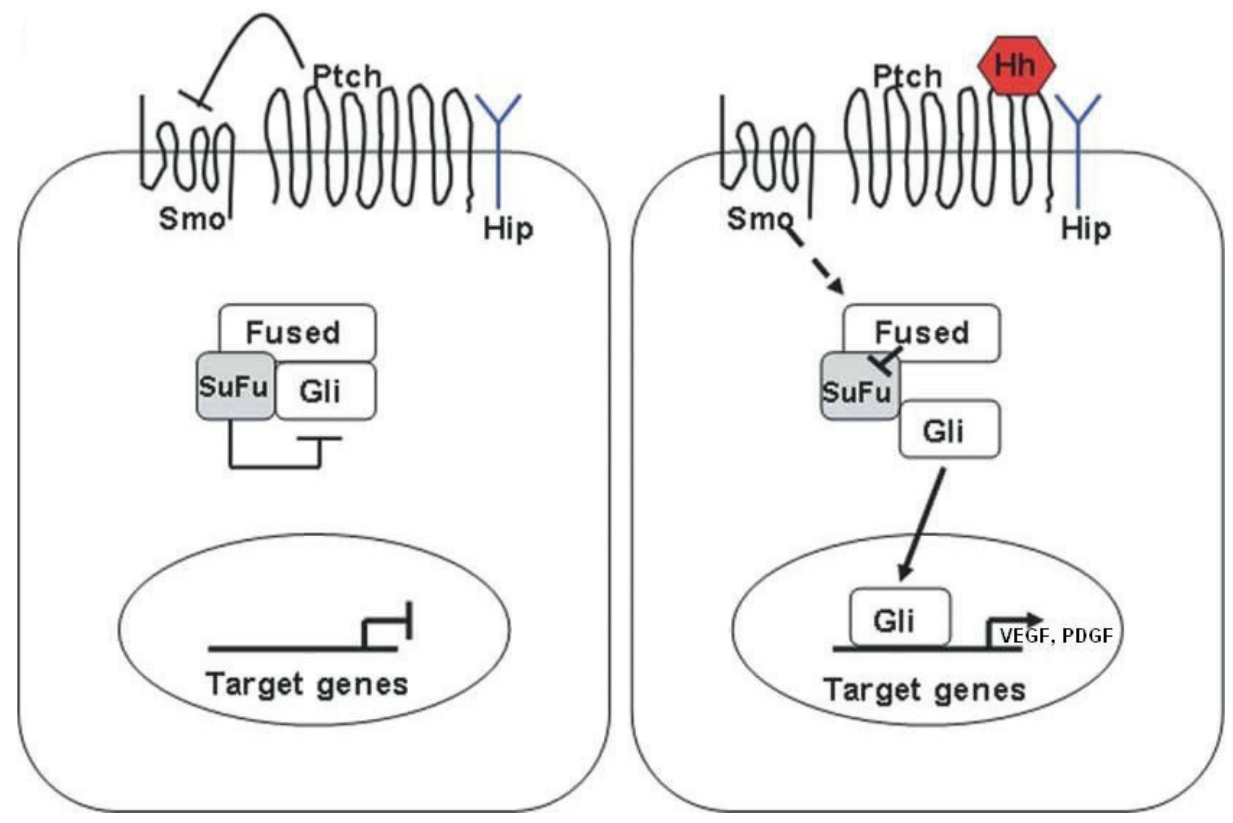

Figure 3. Hedgehog signaling

PTCH represses the SMO activity. After activation of signalisation by Hedgehog ligand the SMO inhibition by PTCH is stopped and SMO governs the suppression of Supressor of Fused ( $\mathrm{SuFu}$ ) in protein complex with Fused (Fu). Then the members of GLI family transcription factors are released from the zinc-finger type protein complex Fu/SuFu. It leads to their translocation into the nucleus and subsequent transcription of target genes [106].

Endocytosis does not operate only in NICD (Notch intracellular domain) transport into the nucleus. It also participates in NICD degradation and recycling and, in activation of Notch receptors. In this way it prevents the continual activation of Notch signaling. NOTCH monoubiquitination with subsequent endocytosis is required before the cleavage of $\mathrm{NOTCH}$ by $\gamma$-secretase [93 94]. NICD directs to the nucleus after Notch signaling activation and there it guides target genes transcription. In contrast, when NICD associates with a lysosome by ESCRT (endosomal sorting complex required for transport) it leads to NICD degradation. When NICD is ubiquitinylated by E3 ubiquitin ligase Deltex (DX), it is transported back to the membrane for NOTCH recyclation [95-98].

The Notch signaling pathway may bypass transcription factor CSL (C-promoter binding factor1, RBP-jk/Su(H)/ Lag-1) and thus activates genes expression in other ways. For example, shaggy-dependent $(\mathrm{Su}(\mathrm{H})$-independent) transcription is driven by a type of Notch allele called Abruptex $(A x)$ in Drosophila. Shaggy encodes the Drosophila homologue of GSK3 $\beta$, which is how Notch and Wnt signaling are connected $[99,100]$. There is also evidence on the effect of Notch signaling on $\beta$-catenin in vertebrates. For example, Notch 1 supresses $\beta$-catenin-mediated signaling in mouse skin and therefore may be considered a tumor suppressor [101]. A conserved sequence of double TCF/LEF-binding sites in the JAG1 promoter is another example of Notch and $\beta$-catenin cooperation. JAG1 expression by the complex of $\beta$-catenin with the TCF/LEF transcription factor may be the first step in Notch signaling activation in progenitor cells for maintaining their homeostasis [35].

Notch1 signaling contributes to 533 inhibition through the mTOR (mammalian target of rapamycin)-dependent PI3KAkt/PKB (protein kinase B) pathway. When mTOR is mutated or NOTCH1 signaling is aberrantly activated, the cells can avoid apoptosis [92]. Another way of aberrant NOTCH1 activation is through oncogenic H-RAS. This route is associated with the emergence of chemoresistance [102]. JAG1 expression arises in CSCs and activates signalization via NOTCH1 during radiotherapy. As a result the genes supporting proliferation are transcribed (Cyclin D1, CDK2) and the tumor gains the potential for radioresistance [103]. This can explain why radiotherapy may have similar effect on both Notch signaling and $\mathrm{Wnt} / \beta$-catenin pathway activation.

In breast cancer, gastrointestinal and certain haematological tumors, Notch signaling governs the stem cell self-renewal and cell-fate decisions and it may act as an oncogene. However, in keratinocyte-derived tumors, the Notch signaling supports terminal differentiation [68] and in some types of lung tumor subtypes [adenocarcinoma, small cell lung cancer (SCLC)], the activation of Notch1 inhibits the growth of tumors [104, 105]. Therefore it can serve either as protooncogen or tumor suppressor depending on the context.

Hedgehog signaling pathway. In mammals, there are 3 types of secreted glycoprotein ligands: Sonic Hedgehog (SHH), Indian Hedgehog (IHH) and Desert Hedgehog (DHH). These bind to the 7-TM receptor Patched (PTCH) associated with 
the second TM receptor Smoothened (SMO) and activate the signaling (Fig. 3) [106]. Target genes (GLI1, PTCH1, Cyclin D, Cyclin E, MYC, VEGF, PDGF, etc.) are able to control tissue patterning, differentiation, proliferation and migration [31, 107, 108]. Hedgehog signaling activation is attenuated by the presence of Hedgehog-interacting protein (HIP) near $\mathrm{PTCH}$, that uptakes Hedgehog ligands [109]. Transcription factors GLI1 and GLI2 serve as positive regulators of Hedgehog signaling pathways, but GLI3 is a negative regulator [110]. Most involved genes are oncogenes but for example PTCH1 is a tumor suppressor [111].

Hedgehog signaling is involved in the development of many organs including mammary gland, pancreas, lung, skin and hair follicle and central nervous system [112-116]. Signaling through SHH facilitates the differentiation of human ESCs, but under other conditions Hedgehog signaling supports their proliferation [117]. In tissue stem/progenitor cells, Hedgehog activity is high, but it is downregulated during the cell differentiation [118]. Thus, Hedgehog signaling promotes survival and proliferation of stem/progenitor cells, rather than the management of cell-fate determination and differentiation [116]. It all depends on the cooperation with other signaling pathways. Among these signaling pathways are Wnt, Notch and PI3K/Akt pathways $[86,119,120]$. In adults, the activity of Hedgehog signaling has to be exactly defined in time and space and there is an unlimited capacity for self-renewal [31, 108]. This means that Hedgehog signaling plays a crucial role in carcinogenesis and metastasis [111].

The disturbances in Hedgehog pathway are commonly observed in a large number of tumors, e.g. medulloblastoma, basal cell carcinoma, stomach, colon, pancreatic, prostate and breast carcinomas [100, 111, 112, 121-123]. The HedgehogGLI1 pathway has an essential role in promoting growth, self-renewal and the metastatic potential of CSCs in colon cancer. In mice it operates in paracrine fashion, whereas in humans in autocrine fashion $[124,125]$.

PTCH loses its tumor suppressor effect either through germline mutations or through silencing of $P T C H$ after methylation in the medulloblastoma. This signaling can be stopped with cyclopamine, the SMO inhibitor downstream PTCH. This leads to reduced proliferation and induction of differentiation $[126,127]$. The SHH and mTOR signaling may be essential for CSCs self-renewal in pancreatic cancer. On the other hand, the targeting of these pathways by cyclopamine and paramycine is not enough to eliminate pancreatic CSCs. The CSCs were eliminated only after adding gemcitabine, as a standard chemotherapy agent. This means that the combination of targeted therapy and standard chemotherapy could be effective in the elimination of CSCs [128]. The Hedgehog signaling may be also inhibited by treatment with forkoskolin that activates the protein kinase A (PKA). The level of cell cAMP (cyclic adenosine monophosphate) is increased after stimulation of adenylyl cyclase [129], which is commonly a sign of energy depletion in the cell. Then the cell enters apoptosis. Conversely, certain agents are known to amplify the activation of Hedgehog signaling pathway. These are, for example the co-conjugates of chondroitin-6-sulfate with dermatan sulfate. These together increase the expression of $\mathrm{IHH}$ [130].

Since Hedgehog signaling promotes stem cells proliferation and prevents their differentiation or entry into apoptosis, it creates appropriate conditions for the accumulation of various genetic events [110]. This is an excellent basis for further detailed research to clarify the involvement of this pathway in chemo- and radioresistance.

\section{Conclusion}

The CSCs and ESCs have the ability for self-renewal and differentiation, and they are also able to exclude "toxic" substances from the cell through certain membrane transporters. CSCs in solid tumors are more similar to normal tissue stem cells than to ESCs because CSCs have determined the direction of differentiation and thus they are using competent signaling pathways. ESCs from the inner cell mass of blastocyst are just deciding about the direction of further development. Therefore the signaling pathways in ECSs are only involved in self-renewal and proliferation. The Wnt, Notch and Hedgehog signaling pathways are activated in ESCs only during their differentiation. These pathways can also be actived during carcinogenesis and are also involved in the emergence of drug resistance by regulating their target genes such as ABCC4 (known as MRP4) and antiapoptotic BCL-2. The detailed understanding of the role of these pathways in radio- and chemoresistance however requires further research.

Acknowledgements: This work was supported by grants IGA MZ CR 10259-3, 9959-3, GACR 303/09/H048, LF_2011_009, MSM 6198959216 and CZ.1.05/2.1.00/01.0030.

\section{References}

[1] LEE CJ, DOSCH J, SIMEONE DM Pancreatic Cancer Stem Cells. J Clin Oncol 2008; 26: 2806-2812. http://dx.doi. org/10.1200/JCO.2008.16.6702

[2] MASSARD C, DEUTSCH E, SORIA JC Tumour stem cell-targeted treatment: elimination or differentiation. Ann Oncol 2006; 17: 1620-1624. http://dx.doi.org/10.1093/annonc/mdl074

[3] PAN G, LI J, ZHOU Y, ZHENG H, PEI D A negative feedback loop of transcription factors that controls stem cell pluripotency and self-renewal. FASEB J 2006; 20: 1730-1732. http://dx.doi.org/10.1096/fj.05-5543fje

[4] VIEYRA D, ROSEN A, GOODELL M Identification and Characterization of SP Cells in ESC Cultures. Stem Cells Dev 2009; 18: 1155-1166. http://dx.doi.org/10.1089/scd.2008.0391

[5] AL-HAJJ M, WICHA MS, BENITO-HERNANDEZ A, MORRISON SJ, CLARKE MF Prospective identification of tumorigenic breast cancer cells. Proc Natl Acad Sci USA 2003; 100: 3983-3988. http://dx.doi.org/10.1073/pnas.0530291100

[6] MARTIN GR Isolation of a pluripotent cell line from early mouse embryos cultured in medium conditioned by tera- 
tocarcinoma stem cells. Proc Natl Acad Sci USA 1981; 78: 7634-7638. http://dx.doi.org/10.1073/pnas.78.12.7634

[7] THOMSON JA, ITSKOVITZ-ELDOR J, SHAPIRO SS, WAKNITZ MA, SWIERGIEL JJ et al. Embryonic stem cell lines derived from human blastocysts. Science 1998; 282: 11451147. http://dx.doi.org/10.1126/science.282.5391.1145

[8] WU XZ Origin of cancer stem cells: the role of self-renewal and differentiation. Ann Surg Oncol 2008; 15: 407-414. http:// dx.doi.org/10.1245/s10434-007-9695-y

[9] DELLATORE SM, GARCIA AS, MILLER WM Mimicking stem cell niches to increase stem cell expansion. Curr Opin Biotechnol 2008; 19: 534-540. http://dx.doi.org/10.1016/ j.copbio.2008.07.010

[10] MALANCHI I, HUELSKEN J Cancer stem cells: never Wnt away from the niche. Curr Opin Oncol 2009; 21: 41-46. http:// dx.doi.org/10.1097/CCO.0b013e32831d1faf

[11] GOODELL MA, BROSE K, PARADIS G, CONNER AS, MULLIGAN RC Isolation and functional properties of murine hematopoietic stem cells that are replicating in vivo. J Exp Med 1996; 183: 1797-1806. http://dx.doi.org/10.1084/ jem.183.4.1797

[12] PATRAWALA L, CALHOUN T, SCHNEIDER-BROUSSARD $\mathrm{R}, \mathrm{ZHOU}$ J, CLAYPOOL $\mathrm{K}$ et al. Side population is enriched in tumorigenic, stem-like cancer cells, whereas ABCG2+ and ABCG2- cancer cells are similarly tumorigenic. Cancer Res 2005; 65: 6207-6219. http://dx.doi.org/10.1158/0008-5472. CAN-05-0592

[13] LEVINA V, MARRANGONI AM, DEMARCO R, GORELIK E, LOKHSIN AE Drug-selected human lung cancer stem cells: cytokine network, tumorigenic and metastatic properties. PLoS ONE 2008; 3: e3077. http://dx.doi.org/10.1371/journal. pone. 0003077

[14] RAMALHO-SANTOS M, YOON S, MATSUZAKI Y, MULLIGAN RC, MELTON DA „Stemness“: transcriptional profiling of embryonic and adult stem cells. Science 2002; 298: 597-600. http://dx.doi.org/10.1126/science.1072530

[15] CROKER AK, ALLAN AL Cancer stem cells: implications for the progression and treatment of metastatic disease. J Cell Mol Med 2008; 12: 374-390. http://dx.doi.org/10.1111/j.15824934.2007.00211.X

[16] PARK CY, TSENG D, WEISSMAN IL Cancer stem cell-directed therapies: recent data from the laboratory and clinic. Mol Ther 2009; 17: 219-230. http://dx.doi.org/10.1038/mt.2008.254

[17] GARCIA-BARROS M, PARIS F, CORDON-CARDO C, LYDEN D, RAFII $S$ et al. Tumor response to radiotherapy regulated by endothelial cell apoptosis. Science 2003; 300: 1155-1159. http://dx.doi.org/10.1126/science.1082504

[18] PARIS F, FUKS Z, KANG A, CAPODIECI P, JUAN G et al. Endothelial apoptosis as the primary lesion initiating intestinal radiation damage in mice. Science 2001; 293: 293-297. http://dx.doi.org/10.1126/science.1060191

[19] LORUSSO G, RUEGG C The tumor microenvironment and its contribution to tumor evolution toward metastasis. Histochem Cell Biol 2008; 130: 1091-1103. http://dx.doi. org/10.1007/s00418-008-0530-8

[20] MOELLER BJ, DREHER MR, RABBANI ZN, SCHROEDER T, CAO Y et al. Pleiotropic effects of HIF-1 blockade on tumor radiosensitivity. Cancer Cell 2005; 8: 99-110. http://dx.doi. org/10.1016/j.ccr.2005.06.016

[21] CALABRESE C, POPPLETON H, KOCAK M, HOGG TL, FULLER $C$ et al. A perivascular niche for brain tumor stem cells. Cancer Cell 2007; 11: 69-82. http://dx.doi.org/10.1016/ j.ccr.2006.11.020

[22] CHEN YC, HSU HS, CHEN YW, TSAI TH, HOW CK et al. Oct-4 expression maintained cancer stem-like properties in lung cancer-derived CD133-positive cells. PLoS ONE 2008; 3: e2637. http://dx.doi.org/10.1371/journal.pone.0002637

[23] WANG ZX, TEH CH, KUEH JL, LUFKIN T, ROBSON P et al. Oct4 and Sox 2 directly regulate expression of another pluripotency transcription factor, Zfp206, in embryonic stem cells. J Biol Chem 2007; 282: 12822-12830. http://dx.doi. org/10.1074/jbc.M611814200

[24] LIM LS, LOH YH, ZHANG W, LI Y, CHEN X et al. Zic3 is required for maintenance of pluripotency in embryonic stem cells. Mol Biol Cell 2007; 18: 1348-1358. http://dx.doi. org/10.1091/mbc.E06-07-0624

[25] WESTERN P, MALDONADO-SALDIVIA J,VAN DEN BERGEN, HAJKOVA P, SAITOU $\mathrm{M}$ et al. Analysis of Esg1 expression in pluripotent cells and the germline reveals similarities with Oct 4 and Sox 2 and differences between human pluripotent cell lines. Stem Cells 2005; 23: 1436-1442. http://dx.doi.org/10.1634/stemcells.2005-0146

[26] WOODWARD WA, CHEN MS, BEHBOD F, ROSEN JM On mammary stem cells. J Cell Sci 2005; 118: 3585-3594. http://dx.doi.org/10.1242/jcs.02532

[27] XIAO L, YUAN X, SHARKIS SJ Activin A maintains selfrenewal and regulates fibroblast growth factor, Wnt, and bone morphogenic protein pathways in human embryonic stem cells. Stem Cells 2006; 24: 1476-1486. http://dx.doi. org/10.1634/stemcells.2005-0299

[28] OKOYE UC, MALBON CC, WANG HY Wnt and Frizzled RNA expression in human mesenchymal and embryonic (H7) stem cells. J Mol Signal 2008; 3: 16. http://dx.doi. org/10.1186/1750-2187-3-16

[29] WALSH J, ANDREWS PW Expression of Wnt and Notch pathway genes in a pluripotent human embryonal carcinoma cell line and embryonic stem cell. APMIS 2003; 111: 197-210. http://dx.doi.org/10.1034/j.1600-0463.2003.1110124.x

[30] PINSON KI, BRENNAN J, MONKLEY S, AVERY BJ, SKARNES WC An LDL-receptor-related protein mediates Wnt signalling in mice. Nature 2000; 407: 535-538. http:// dx.doi.org/10.1038/35035124

[31] LIU S, DONTU G, WICHA MS Mammary stem cells, selfrenewal pathways, and carcinogenesis. Breast Cancer Res 2005; 7: 86-95. http://dx.doi.org/10.1186/bcr1021

[32] BARKER N: The canonical Wnt/beta-catenin signalling pathway. Methods Mol Biol 2008; 468: 5-15. http://dx.doi. org/10.1007/978-1-59745-249-6_1

[33] DIHLMANN S, VON KNEBEL DOEBERITZ M Wnt/betacatenin-pathway as a molecular target for future anti-cancer therapeutics. Int J Cancer 2005; 113: 515-524. http://dx.doi. org/10.1002/ijc.20609

[34] DU Q, PARK KS, GUO Z, HE P, NAGASHIMA M et al. Regulation of human nitric oxide synthase 2 expression by 
Wnt beta-catenin signaling. Cancer Res 2006; 66: 7024-7031. http://dx.doi.org/10.1158/0008-5472.CAN-05-4110

[35] Katoh M, KATOH M Notch ligand, JAG1, is evolutionarily conserved target of canonical WNT signaling pathway in progenitor cells. Int J Mol Med 2006; 17: 681-685.

[36] KATOH M, KATOH M CER1 is a common target of WNT and NODAL signaling pathways in human embryonic stem cells. Int J Mol Med 2006; 17: 795-799.

[37] KATOH M, KATOH M WNT signaling pathway and stem cell signaling network. Clin Cancer Res 2007; 13: 4042-4045. http://dx.doi.org/10.1158/1078-0432.CCR-06-2316

[38] THOMPSON MC, FULLER C, HOGG TL, DALTON J, FINKELSTEIN D et al. Genomics identifies medulloblastoma subgroups that are enriched for specific genetic alterations. J Clin Oncol 2006; 24: 1924-1931. http://dx.doi.org/10.1200/ JCO.2005.04.4974

[39] Chiba T, ZHENG YW, KITA K, YOKOSUKA O, SAISHO H et al. Enhanced self-renewal capability in hepatic stem/progenitor cells drives cancer initiation. Gastroenterology 2007; 133: 937-950. http://dx.doi.org/10.1053/i.gastro.2007.06.016

[40] YOOK JI, LI XY, OTA I, FEARON ER, WEISS SJ Wnt-dependent regulation of the E-cadherin repressor snail. J Biol Chem 2005; 280: 11740-11748. http://dx.doi.org/10.1074/jbc. M413878200

[41] SCHLANGE T, MATSUDA Y, LIEMHARD S, HUBER A, HYNES NE Autocrine WNT signaling contributes to breast cancer cell proliferation via the canonical WNT pathway and EGFR transactivation. Breast Cancer Res 2007; 9: R63. http://dx.doi.org/10.1186/bcr1769

[42] KAWANO Y, KYPTA R Secreted antagonists of the Wnt signalling pathway. J Cell Sci 2003; 116: 2627-2634. http://dx.doi. org/10.1242/jcs.00623

[43] SELL S Stem cell origin of cancer and differentiation therapy. Crit Rev Oncol Hematol 2004; 51: 1-28. http://dx.doi.org/ 10.1016/j.critrevonc.2004.04.007

[44] WANG S, SHEN Y, YUAN X, CHEN K, GUO X et al. Dissecting signaling pathways that govern self-renewal of rabbit embryonic stem cells. J Biol Chem 2008; 283: 35929-35940. http://dx.doi.org/10.1074/jbc.M804091200

[45] DRAVID G, YE Z, HAMMOND H, CHEN G, PYLE A et al. Defining the role of Wnt/beta-catenin signaling in the survival, proliferation, and self-renewal of human embryonic stem cells. Stem Cells 2005; 23: 1489-1501. http://dx.doi.org/10.1634/ stemcells.2005-0034

[46] NAITO AT, SHIOJIMA I, AKAZAWA H, HIDAKA K, MORISAKI $\mathrm{T}$ et al. Developmental stage-specific biphasic roles of Wnt/beta-catenin signaling in cardiomyogenesis and hematopoiesis. Proc Natl Acad Sci U S A 2006; 103: $19812-$ 19817. http://dx.doi.org/10.1073/pnas.0605768103

[47] SUMI T, TSUNEYOSHI N, NAKATSUJI N, SUEMORI H Defining early lineage specification of human embryonic stem cells by the orchestrated balance of canonical Wnt/beta-catenin, Activin/Nodal and BMP signaling. Development 2008; 135: 2969-2979. http://dx.doi.org/10.1242/dev.021121

[48] JAMES D, LEVINE AJ, BESSER D, HEMMATI-BRIVANLOU A TGFbeta/activin/nodal signaling is necessary for the maintenance of pluripotency in human embryonic stem cells.
Development 2005; 132: 1273-1282. http://dx.doi.org/10.1242/ dev.01706

[49] ALMEIDA M, HAN L, BELLIDO T, MANOLAGAS SC, KOUSTENI S Wnt proteins prevent apoptosis of both uncommitted osteoblast progenitors and differentiated osteoblasts by beta-catenin-dependent and -independent signaling cascades involving Src/ERK and phosphatidylinositol 3-kinase/AKT. J Biol Chem 2005; 280: 41342-41351. http://dx.doi.org/10.1074/ jbc.M502168200

[50] VALLIER L, ALEXANDER M, PEDERSEN RA Activin/Nodal and FGF pathways cooperate to maintain pluripotency of human embryonic stem cells. J Cell Sci 2005; 118: 4495-4509. http://dx.doi.org/10.1242/jcs.02553

[51] MULHOLLAND DJ, DEDHAR S, COETZEE GA, NELSON CC Interaction of nuclear receptors with the Wnt/beta-catenin/Tcf signaling axis: Wnt you like to know? Endocr Rev 2005; 26: 898-915. http://dx.doi.org/10.1210/er.2003-0034

[52] SHAH S, HECHT A, PESTELL R, BYERS SW Trans-repression of beta-catenin activity by nuclear receptors. J Biol Chem 2003; 278: 48137-48145. http://dx.doi.org/10.1074/jbc.M307154200

[53] IDOGAWA M, MASUTANI M, SHITASHIGE M, HONDA K, TOKINO T et al. Ku70 and poly(ADP-ribose) polymerase-1 competitively regulate beta-catenin and T-cell factor-4-mediated gene transactivation: possible linkage of DNA damage recognition and Wnt signaling. Cancer Res 2007; 67: 911-918. http://dx.doi.org/10.1158/0008-5472.CAN-06-2360

[54] YUAN D, LIU L, GU D Transcriptional regulation of livin by beta-catenin/TCF signaling in human lung cancer cell lines. Mol Cell Biochem 2007; 306: 171-178. http://dx.doi. org/10.1007/s11010-007-9567-6

[55] HADJIHANNAS MV, BRUCKNER M, JERCHOW B, BIRCHMEIER W, DIETMAIER W et al. Aberrant Wnt/beta-catenin signaling can induce chromosomal instability in colon cancer. Proc Natl Acad Sci U S A 2006; 103: 10747-10752. http:// dx.doi.org/10.1073/pnas.0604206103

[56] CHEN MS, WOODWARD WA, BEHBOD F, PEDDIBHOTLA $\mathrm{S}$, ALFARO MP et al. Wnt/beta-catenin mediates radiation resistance of Sca1+ progenitors in an immortalized mammary gland cell line. J Cell Sci 2007; 120: 468-477. http://dx.doi. org/10.1242/jcs.03348

[57] REID G, WIELINGA P, ZELCER N, DE HAAS M, VAN DEEMTER L et al. Characterization of the transport of nucleoside analog drugs by the human multidrug resistance proteins MRP4 and MRP5. Mol Pharmacol 2003; 63: 10941103. http://dx.doi.org/10.1124/mol.63.5.1094

[58] TENG Y, WANG X, WANG Y, MA D Wnt/beta-catenin signaling regulates cancer stem cells in lung cancer A549 cells. Biochem Biophys Res Commun 2010; 392: 373-379. http://dx.doi.org/10.1016/j.bbrc.2010.01.028

[59] VERMEULEN L, DE SOUSA E, MELO F, VAN DER HEIJDEN $\mathrm{M}, \mathrm{CAMERON} \mathrm{K}$ et al. Wnt activity defines colon cancer stem cells and is regulated by the microenvironment. Nat Cell Biol 2010; 12: 468-476. http://dx.doi.org/10.1038/ncb2048

[60] KATOH M, KATOH M STAT3-induced WNT5A signaling loop in embryonic stem cells, adult normal tissues, chronic persistent inflammation, rheumatoid arthritis and cancer (Review). Int J Mol Med 2007; 19: 273-278. 
[61] DIHLMANN S, SIERMANN A, VON KNEBEL DOEBERITZ M The nonsteroidal anti-inflammatory drugs aspirin and indomethacin attenuate beta-catenin/TCF-4 signaling. Oncogene 2001; 20: 645-653. http://dx.doi.org/10.1038/ si.onc. 1204123

[62] SHAH S, PISHVAIAN MJ, EASWARAN V, BROWN PH, BYERS SW The role of cadherin, beta-catenin, and AP-1 in retinoid-regulated carcinoma cell differentiation and proliferation. J Biol Chem 2002; 277: 25313-25322. http://dx.doi. org/10.1074/jbc.M203158200

[63] PALMER HG, GONZALEZ-SANCHO JM, ESPADA J, BERCIANO MT, PUIG I et al. Vitamin D(3) promotes the differentiation of colon carcinoma cells by the induction of E-cadherin and the inhibition signaling. J Cell Biol 2001; 154: 369-387. http://dx.doi.org/10.1083/jcb.200102028

[64] RAO AS, KREMENEVSKAJA N, VON WASIELEWSKI R, JAKUBCAKOVA V, KANT S et al. Wnt/beta-catenin signaling mediates antineoplastic effects of imatinib mesylate (gleevec) in anaplastic thyroid cancer. J Clin Endocrinol Metab 2006; 91: 159-168. http://dx.doi.org/10.1210/jc.2005-1381

[65] TAKAHASHI-YANAGA F, SASAGURI T: The Wnt/betacatenin signaling pathway as a target in drug discovery. J Pharmacol Sci 2007; 104: 293-302. http://dx.doi.org/10.1254/ jphs.CR0070024

[66] ZHANG Q, MAJOR MB, TAKANASHI S, CAMP ND, NISHIYA N et al. Small-molecule synergist of the Wnt/betacatenin signaling pathway. Proc Natl Acad Sci U S A 2007; 104: 7444-7448. http://dx.doi.org/10.1073/pnas.0702136104

[67] MIYABAYASHI T, TEO JL, YAMAMOTO M, MCMILLAN M, NGUYEN C et al. Wnt/beta-catenin/CBP signaling maintains long-term murine embryonic stem cell pluripotency. Proc Natl Acad Sci U S A 2007; 104: 5668-5673. http://dx.doi. org/10.1073/pnas.0701331104

[68] BOLOS V, BLANCO M, MEDINA V, APARICIO G, DIAZPRADO $S$ et al. Notch signalling in cancer stem cells. Clin Transl Oncol 2009; 11: 11-19. http://dx.doi.org/10.1007/ $\underline{\text { s12094-009-0305-2 }}$

[69] FIUZA UM, ARIAS AM Cell and molecular biology of Notch. J Endocrinol 2007; 194: 459-474. http://dx.doi.org/10.1677/ JOE-07-0242

[70] KLEIN T, BRENNAN K, ARIAS AM An intrinsic dominant negative activity of serrate that is modulated during wing development in Drosophila. Dev Biol 1997; 189: 123-134. http://dx.doi.org/10.1006/dbio.1997.8564

[71] LOWELL S, JONES P, LE ROUX I, DUNNE J, WATT FM Stimulation of human epidermal differentiation by deltanotch signalling at the boundaries of stem-cell clusters. Curr Biol 2000; 10: 491-500. http://dx.doi.org/10.1016/S09609822(00)00451-6

[72] WU Y, ZHOU BP New insights of epithelial-mesenchymal transition in cancer metastasis. Acta Biochim Biophys Sin (Shanghai) 2008; 40: 643-650. http://dx.doi.org/10.1111/ j.1745-7270.2008.00443.x

[73] AULEHLA A, WEHRLE C, BRAND-SABERI B, KEMLER $\mathrm{R}$, GOSSLER A et al. Wnt3a plays a major role in the segmentation clock controlling somitogenesis. Dev Cell 2003; 4: 395-406. http://dx.doi.org/10.1016/S1534-5807(03)00055-8
[74] CONLON RA, REAUME AG, ROSSANT J Notch1 is required for the coordinate segmentation of somites. Development 1995; 121: 1533-1545.

[75] PARKS AL, HUPPERT SS, MUSKAVITCH MAT The dynamic of neuronic signalling underlying bristle development in Drosophila melanogaster. Mech Dev 1997; 63: 61-74. http://dx.doi. org/10.1016/S0925-4773(97)00675-8

[76] KIERNAN AE, CORDES R, KOPAN R, GOSSLER A, GRIDLEY T The Notch ligands DLL1 and JAG2 act synergistically to regulate hair cell development in the mammalian inner ear. Development 2005; 132: 4353-4362. http://dx.doi.org/10.1242/ dev.02002

[77] CHIBA S Notch signaling in stem cell systems. Stem Cells 2006; 24: 2437-2447. http://dx.doi.org/10.1634/stemcells.2005$\underline{0661}$

[78] KITA A, IMAYOSHI I, HOJO M, KITAGAWA M, KOKUBU H et al. Hes 1 and Hes 5 Control the Progenitor Pool,Intermediate Lobe Specification, and Posterior Lobe Formation in the Pituitary Development. Mol Endocrinol 2007; 21: 1458-1466. http://dx.doi.org/10.1210/me.2007-0039

[79] LEE CS, KAESTNER KH Clinical endocrinology and metabolism. Development of gut endocrine cells. Best Pract Res Clin Endocrinol Metab 2004; 18: 453-462. http://dx.doi. org/10.1016/j.beem.2004.08.008

[80] NOGGLE SA, WEILER D, CONDIE BG Notch signaling is inactive but inducible in human embryonic stem cells. Stem Cells 2006; 24: 1646-1653. http://dx.doi.org/10.1634/ stemcells.2005-0314

[81] MOLOFSKY AV, PARDAL R, MORRISON SJ Diverse mechanisms regulate stem cell self-renewal. Curr Opin Cell Biol 2004; 16: 700-707. http://dx.doi.org/10.1016/j.ceb.2004.09.004

[82] SCHMITT TM, DE POOTERRF, GRONSKI MA et al. Induction of $\mathrm{T}$ cell development and establishment of $\mathrm{T}$ cell competence from embryonic stem cells differentiatied in vitro. Nat Immunol 2004; 5: 410-417. http://dx.doi.org/10.1038/ni1055

[83] LUTOLF S, RADTKE F, AGUET M, SUTER U, TAYLOR V Notch1 is required for neuronal and glial differentiation in the cerebellum. Development 2002; 129: 373-385.

[84] OHTSUKA T, SAKAMOTO M, GUILLEMOT F, KAGEYAMA $\mathrm{R}$ Roles of the basic helix-loop-helix genes Hes1 and Hes5 in expansion of neural stem cells of the developing brain. J Biol Chem 2001; 276: 30467-30474. http://dx.doi.org/10.1074/jbc. M102420200

[85] RAMASAMY SK, LENKA N Notch exhibits ligand bias and maneuvers stage-specific steering of neural differentiation in embryonic stem cells. Mol Cell Biol 2010; 30: 1946-1957. http://dx.doi.org/10.1128/MCB.01419-09

[86] CRAWFORD TQ, ROELINK H The notch response inhibitor DAPT enhances neuronal differentiation in embryonic stem cell-derived embryoid bodies independently of sonic hedgehog signaling. Dev Dyn 2007; 236: 886-892. http://dx.doi. org/10.1002/dvdy.21083

[87] DONTU G, JACKSON KW, MCNICHOLAS E, KAWAMURA MJ, ABDALLAH WM et al. Role of Notch signaling in cellfate determination of human mammary stem/progenitor cells. Breast Cancer Res 2004; 6: R605-615. http://dx.doi. org/10.1186/bcr920 
[88] DEVGAN V, MAMMUCARI C, MILLAR SE, BRISKEN C, DOTTO GP $\mathrm{p} 21 \mathrm{WAF} 1 / \mathrm{Cip} 1$ is a negative transcriptional regulator of Wnt4 expression downstream of Notch1 activation. Genes Dev 2005; 19: 1485-1495. http://dx.doi.org/10.1101/ gad.341405

[89] NOSEDA M, CHANG L, MCLEAN G, GRIM JE, CLURMAN $\mathrm{BE}$ et al. Notch activation induces endothelial cell cycle arrest and participates in contact inhibition: role of p21Cip1 repression. Mol Cell Biol 2004; 24: 8813-8822. http://dx.doi. org/10.1128/MCB.24.20.8813-8822.2004

[90] LIU ZJ, XIAO M, BALINT K, SOMA A, PINNIX CC et al. Inhibition of endothelial cell proliferation by Notch1 signaling is mediated by repressing MAPK and PI3K/Akt pathways and requires MAML1. FASEB J 2006; 20: 1009-1011. http://dx.doi. org/10.1096/fj.05-4880fje

[91] KANG DE, YOON IS, REPETTO E, BUSSE T, YERMIAN N et al. Presenilins mediate phosphatidylinositol 3-kinase/AKT and ERK activation via select signaling receptors. Selectivity of PS2 in platelet-derived growth factor signaling. J Biol Chem 2005; 280: 31537-31547. http://dx.doi.org/10.1074/jbc. $\underline{\mathrm{M} 500833200}$

[92] MUNGAMURI SK, YANG X, THOR AD, SOMASUNDARAM K Survival signaling by Notch1: mammalian target of rapamycin (mTOR)-dependent inhibition of p53. Cancer Res 2006; 66: 4715-4724. http://dx.doi.org/10.1158/0008-5472. CAN-05-3830

[93] GUPTA-ROSSI N, SIX E, LEBAIL O, LOGEAT F, CHASTAGNER $P$ et al. Monoubiquitination and endocytosis direct gamma-secretase cleavage of activated Notch receptor. JCell Biol 2004; 166: 73-83. http://dx.doi.org/10.1083/jcb.200310098

[94] SEUGNET L, SIMPSON P, HAENLIN M Requirement for dynamin during Notch signaling in Drosophila neurogenesis. Dev Biol 1997; 192: 585-598. http://dx.doi. org/10.1006/dbio.1997.8723

[95] WILKIN MB, CARBERY AM, FOSTIER M, ASLAM H, MAZALEYRAT SL et al. Regulation of notch endosomal sorting and signaling by Drosophila Nedd4 family proteins. Curr Biol 2004; 14: 2237-2244. http://dx.doi.org/10.1016/ j.cub.2004.11.030

[96] HORI K, FOSTIER M, ITO M, FUWA TJ, GO MJ et al. Drosophila deltex mediates suppressor of Hairless-independent and late-endosomal activation of Notch signaling. Development 2004; 131: 5527-5537. http://dx.doi.org/10.1242/ dev.01448

[97] LE BORGNE R Regulation of Notch signalling by endocytosis and endosomal sorting. Curr Opin Cell Biol 2006; 18: 213-222. http://dx.doi.org/10.1016/i.ceb.2006.02.011

[98] LE BORGNE R, BARDIN A, SCHWEISGUTH F The roles of receptor and ligand endocytosis in regulating Notch signaling. Development 2005; 132: 1751-1762. http://dx.doi.org/10.1242/ dev.01789

[99] BRENNAN K, TATESON R, LIEBER T, COUSO JP,ZECCHINI $\mathrm{V}$ et al. The abruptex mutations of notch disrupt the establishment of proneural clusters in Drosophila. Dev Biol 1999; 216: 230-242. http://dx.doi.org/10.1006/dbio.1999.9501

[100] LAWRENCE N, KLEIN T, BRENNAN K, MARTINEZ ARIAS A Structural requirements for notch signalling with delta and serrate during the development and patterning of the wing disc of Drosophila. Development 2000; 127: $3185-$ 3195.

[101] NICOLAS M, WOLFER A, RAJ K, KUMMER JA, MILL P et al. Notch 1 functions as a tumor suppressor in mouse skin. Nat Genet 2003; 33: 416-421. http://dx.doi.org/10.1038/ ng1099

[102] WEIJZEN S, RIZZO P, BRAID M, VAISHNAV R, JONKHEER SM et al. Activation of Notch-1 signaling maintains the neoplastic phenotype in human Ras-transformed cells. Nat Med 2002; 8: 979-986. http://dx.doi.org/10.1038/nm754

[103] PHILLIPS TM, MCBRIDE WH, PAJONK F The response of CD24(-/low)/CD44+ breast cancer-initiating cells to radiation. J Natl Cancer Inst 2006; 98: 1777-1785. http://dx.doi. org/10.1093/jnci/djj495

[104] ZHENG Q, QIN H, ZHANG H, LI J, HOU L et al. Notch signaling inhibits growth of the human lung adenocarcinoma cell line A549. Oncol Rep 2007; 17: 847-852.

[105] SRIURANPONG V, BORGES MW, RAVI RK, ARNOLD DR, NELKIN BD et al. Notch signaling induces cell cycle arrest in small cell lung cancer cells. Cancer Res 2001; 61: 3200-3205.

[106] KALIRAI H, CLARKE RB Human breast epithelial stem cells and their regulation. J Pathol 2006; 208: 7-16. http://dx.doi. org/10.1002/path. 1881

[107] ECHELARD Y, EPSTEIN DJ, ST-JACQUES B, SHEN L, MOHLER J et al. Sonic hedgehog, a member of a family of putative signaling molecules, is implicated in the regulation of CNS polarity. Cell 1993; 75: 1417-1430. http://dx.doi. org/10.1016/0092-8674(93)90627-3

[108] BALORDI F, FISHELL G Mosaic removal of hedgehog signaling in the adult SVZ reveals that the residual wildtype stem cells have a limited capacity for self-renewal. J Neurosci 2007; 27: 14248-14259. http://dx.doi.org/10.1523/ JNEUROSCI.4531-07.2007

[109] KAWAHIRA H, MA NH, TZANAKAKIS ES, MCMAHON AP, CHUANG PT et al. Combined activities of hedgehog signaling inhibitors regulate pancreas development. Development 2003; 130: 4871-4879. http://dx.doi.org/10.1242/dev.00653

[110] LIU S, DONTU G, MANTLE ID, PATEL S, AHN NS et al. Hedgehog signaling and Bmi-1 regulate self-renewal of normal and malignant human mammary stem cells. Cancer Res 2006; 66: 6063-6071. http://dx.doi.org/10.1158/0008-5472. CAN-06-0054

[111] HUTCHIN ME, KARIAPPER MS, GRACHTCHOUK M, WANG A, WEI L et al. Sustained Hedgehog signaling is required for basal cell carcinoma proliferation and survival: conditional skin tumorigenesis recapitulates the hair growth cycle. Genes Dev 2005; 19: 214-223. http://dx.doi.org/10.1101/ gad. 1258705

[112] HATSELL S, FROST AR Hedgehog signaling in mammary gland development and breast cancer. J Mammary Gland Biol Neoplasia 2007; 12: 163-173. http://dx.doi.org/10.1007/ s10911-007-9048-2

[113] MFOPOU JK, BOUWENS L Hedgehog signals in pancreatic differentiation from embryonic stem cells: revisiting the neglected. Differentiation 2008; 76: 107-117. http://dx.doi. org/10.1111/j.1432-0436.2007.00191.x 
[114] VAN TUYL M, POST M From fruitflies to mammals: mechanisms of signalling via the Sonic hedgehog pathway in lung development. Respir Res 2000; 1: 30-35. http://dx.doi. org/10.1186/rr9

[115] ELLIS T, SMYTH I, RILEY E, BOWLES J, ADOLPHE C et al. Overexpression of Sonic Hedgehog suppresses embryonic hair follicle morphogenesis. Dev Biol 2003; 263: 203-215. http://dx.doi.org/10.1016/S0012-1606(03)00394-4

[116] CAI C, THORNE J, GRABEL L Hedgehog serves as a mitogen and survival factor during embryonic stem cell neurogenesis. Stem Cells 2008; 26: 1097-1108. http://dx.doi.org/10.1634/ stemcells.2007-0684

[117] RHO JY, YU K, HAN JS, CHAE JI, KOO DB et al. Transcriptional profiling of the developmentally important signalling pathways in human embryonic stem cells. Hum Reprod 2006; 21: 405-412.

[118] CHARAFE-JAUFFRET E, MONVILLE F, GINESTIER C, DONTU G, BIRNBAUM D et al. Cancer stem cells in breast: current opinion and future challenges. Pathobiology 2008; 75 : 75-84. http://dx.doi.org/10.1159/000123845

[119] HEISER PW, LAU J, TAKETO MM, HERRERA PL, HEBROK M Stabilization of beta-catenin impacts pancreas growth. Development 2006; 133: 2023-2032. http://dx.doi.org/10.1242/ dev.02366

[120] RIOBO NA, LU K, AI X, HAINES GM, EMERSON CP JR Phosphoinositide 3-kinase and Akt are essential for Sonic Hedgehog signaling. Proc Natl Acad Sci U S A 2006; 103: 4505-4510. http://dx.doi.org/10.1073/pnas.0504337103

[121] LEE CJ, DOSCH J, SIMEONE DM Pancreatic Cancer Stem Cells. J Clin Oncol 2008; 26: 2806-2812. http://dx.doi. org/10.1200/JCO.2008.16.6702

[122] KARHADKAR SS, BOVA GS, ABDALLAH N, DHARA S, GARDNER D et al. Hedgehog signalling in prostate regeneration, neoplasia and metastasis. Nature 2004; 431: 707-712. http://dx.doi.org/10.1038/nature02962
[123] MEDINA V, CALVO MB, DIAZ-PRADO S, ESPADA J Hedgehog signalling as a target in cancer stem cells. Clin Transl Oncol 2009; 11: 199-207. http://dx.doi.org/10.1007/s12094009-0341-y

[124] VARNAT F, DUQUET A, MALERBA M, ZBINDEN M, MAS $C$ et al. Human colon cancer epithelial cells harbour active HEDGEHOG-GLI signalling that is essential for tumour growth, recurrence, metastasis and stem cell survival and expansion. EMBO Mol Med 2009; 1: 338-351. http://dx.doi. org/10.1002/emmm.200900039

[125] GULINO A, FERRETTI E, DE SMAELE E Hedgehog signalling in colon cancer and stem cells. EMBO Mol Med 2009; 1: 300-302. http://dx.doi.org/10.1002/emmm.200900042

[126] DEAN M, FOJO T, BATES S Tumour stem cells and drug resistance. Nat Rev Cancer 2005; 5: 275-284. http://dx.doi. org $/ 10.1038 / \mathrm{nrc} 1590$

[127] MASSARD C, DEUTSCH E, SORIA JC Tumour stem cell-targeted treatment: elimination or differentiation. Ann Oncol 2006; 17: 1620-1624. http://dx.doi.org/10.1093/annonc/mdl074

[128] MUELLER MT, HERMANN PC, WITTHAUER J, RUBIO-VIQUEIRA B, LEICHT SF et al. Combined targeted treatment to eliminate tumorigenic cancer stem cells in human pancreatic cancer. Gastroenterology 2009; 137: 1102-1113. http://dx.doi.org/10.1053/j.gastro.2009.05.053

[129] SHINDO N, SAKAI A, ARAI D, MATSUOKA O, YAMASAKI $Y$ et al. The ESC-E(Z) complex participates in the hedgehog signaling pathway. Biochem Biophys Res Commun 2005; 327: 1179-1187. http://dx.doi.org/10.1016/ j.bbrc.2004.12.125

[130] CHEN YL, CHEN HC, CHAN HY, CHUANG CK, CHANG $\mathrm{YH}$ et al. Co-conjugating chondroitin-6-sulfate/dermatan sulfate to chitosan scaffold alters chondrocyte gene expression and signaling profiles. Biotechnol Bioeng 2008; 101: 821-830. http://dx.doi.org/10.1002/bit.21953 